\title{
Advanced Managerial Accounting Techniques and Decision Support System: An Empirical Analysis of Small And Medium Enterprises in Jordan
}

\author{
Wesam Abu Mater \\ H. Kanasro, $P h D$ \\ University of Sindh, Institute of commerce, Pakistan
}

Doi:10.19044/esj.2018.v14n22p233 URL:http://dx.doi.org/10.19044/esj.2018.v14n22p233

\begin{abstract}
This study investigates the empirical analysis of advanced managerial accounting techniques on decision support system in small and medium enterprises in Jordan. The crucial role played by small and medium-sized companies have a major impact on the economies of countries. Therefore, working at maximum cost-effectiveness is vital to both survival and competitiveness because most SMEs in developing countries operate in crowded and competitive markets. To obtain the objectives of the study, the researcher conducted a questionnaire survey, a sample was of 100 managers and 200 employees' respondents was purposefully sampled, in SMEs in Amman capital city of Jordan. The purpose of the sample is to see the effect of accounting management techniques and decision support system in small and medium enterprises and the researcher take the demographic variables; gender, management level, age, education, and use of technology and financial controlling system are taken as moderating variables. The statistical tests were applied to analyze the data. The results of the study showed the significant impact of advanced managerial accounting techniques and decision support on SMEs. The study also found that financial controlling system and the use of technology has a positive impact on performance. In light of the results the researcher has made a number of recommendations that will help the Jordanian enterprises, in order to be able to interact and respond to economic, environmental and social variables and respond to economic, environmental and social variables.
\end{abstract}

Keywords: Managerial Accounting Techniques, Decision Support System, SMEs 


\section{Introduction:}

The world witnessed in the field of business and trade a rapid advance in technology, competition faced by the organizations in the use of managerial accounting techniques to reduce the cost, which in turn is an important development in determining the cost accurately for each of the products, goods and services. It also contributes in about $55 \%$ of the state budget (Al Sayyed, 2015).

On other hand, Al-Khfsh (2015) explained that the small and medium institutions contribute in about 50-70\% of the GDP in the advanced countries, and $39 \%$ in the middle-income economies, and $16 \%$ in the developing countries. Additionally, Jordan is likewise as many other countries depends on the raising of their economy on Small \& Medium Enterprises .

According to (Solomon, 2015) the managerial accounting techniques are a renewable science because of the methods and visions and analyses are many of the modern sciences and can be updated constantly and has an effective role and influence in supporting managers and support in planning and control and evaluate performance and make appropriate decisions. Administrative, accounting began to turn from the traditional entrance to the contemporary entrance where its concepts, dimensions, methods and frameworks evolved to suit the requirements of modern times and the needs of management. A variety of reasons have led to the development of managerial accounting methods, such as the emergence of intense competition among companies producing similar goods, the diversity and multiplicity of consumer tastes, which have increased the proportion of commodity mix and the high proportion of indirect costs for direct costs. Information in light of the economic, environmental and technological changes, many modern financial accounting tools have emerged,

-Activity based costing.

-Target costs.

-Customer profitability analysis.

-Balanced Scorecard

-Just in time

All that is due to the growth factors in the business environment and the barriers in front of the market, property rights, and stationary legislative environment which generally shows a relation between economic growth and the amount of the contribution the small and medium institutions. according to (Al Sayyed, 2015) globalization that have occurred in the area of business has led to the complexity of the administrative procedures of the planning, organizing, directing and controlling, as well as decision-making, due to the diversity of activities carried out by a single company. So increased importance of the use of managerial accounting techniques that enable companies to verify the effective use of available resources to achieve the 
desired goals and using methods to collect information that would help to make sound decisions that reduce the cost of production. The fundamental reason for accounting techniques is helping somebody decide. Despite who is managers level make decision, the comprehension of accounting techniques takes into account a more educated, and better, decision (Horngren, Sundem and Stratton, 2002:4). In spite of the fact that all accounting is money related in the good judgment, the term managerial accounting is risen to improve to a substantial degree the information gave by financial accounting. Be that as it may, it does not supplant financial accounting rather it supplements the financial accounting by serving essential accounting information to the management. Management Accounting would thus be able to be characterized as the way toward distinguishing, measuring, gathering, examining, getting ready, translating, and conveying data that enables directors to satisfy hierarchical targets (Horngren et al., 2002:5). Clear comprehension of managerial accounting has been given by the Management Accounting Team of the Anglo-American Council of Productivity (Maheshwari, 1989: A.8) as "management Accounting is the introduction of accounting information so as to help management in the making of arrangement and in the everyday operations of an endeavor." So one might say that the most concerning components of management accounting are the arrangement and utilization of accounting information by directors inside association; and encouraging the supervisors in their basic leadership and administration control capacities, arranging financial execution and enhancing gainfulness.

\section{Literature review:}

According to the (Al Mansoor, 2010), management accounting techniques and requirements of strategic management can be seen the relationship between methods and techniques of management accounting and the required strategic management of information to achieve competitive advantages and thus the management accounting techniques that could lead to (improve product design, or change in the specifications and characteristics of the materials or modification in the operating modalities).

Zumlot (2013) says that the main functions of the managerial accounting techniques to planning and decision-making where you play management accounting oversight role, and performance evaluation, so accounting administrative several extension methods for decision-makers are used at different levels in the organizational structure of economic unity informative and appropriate to make decisions, whether routine or nonroutine, but with many of the developments in the modern manufacturing environment and the consequent radical changes become an important managerial accounting technique for all companies to achieve the desired goals. 
(Maqbool -Ur- Rehman, 2011) examined the impact of the utilization of management accounting practices on firm gainfulness utilizing a study. Item value, quality, separation, direction changes, innovation and after-deals benefit were estimations of states of rivalry. He found that under intense rivalry customary management accounting practices were more as often as possible utilized as a part of Pakistani assembling firms than contemporary ones. For example, Pakistani organizations favored capital planning methods especially payback period and profit for deals to basic leadership and to assess divisional execution.

Al \& McLellan (2011) investigated the current status of management accounting practices and the ranking by managers of the benefits obtained from the practices using surveys and interviews of senior financial managers in manufacturing companies. Their results indicated that Egyptian manufacturing organizations retained and believed in traditional MAPs which were thought to be suitable in an unstable economy. However, the benefits of advanced MAPs have been increasingly recognized by the managers.

Pepe (2011) argues that advanced technology has strengthened administrative accounting capabilities to interpret data efficiently and effectively. Computers and accounting software have completely changed the industry. With programs like Microsoft Excel, an accountant now had an electronic spreadsheet. The need for adding machines, calculators, ledgers and pencils were eliminated. The job became less annoying with less margin for error. Financial controls help internal control and the operations team have confidence in the numbers reported to management and help protect the assets of the organization. Strong financial controls will allow reliable financial reporting throughout the system, which will make the accounting process more sound financial management. Strong controls also provide more public assurance that the accounting data are correct and the money is better protected against possible fraud. That in turn leads to greater profits for the operations.

Al-Omiri, \& Drury (2007) has led a paper which has been not able build up solid connections between $\mathrm{ABC}$ appropriation and those logical elements that have been recognized in the writing that are helpful for the selection of ABC frameworks. Results show that larger amounts of cost framework advancement are decidedly connected with the significance of cost data, degree of utilization of other inventive administration bookkeeping procedures, power of the aggressive condition, measure, degree of the utilization of JIT/lean creation systems and the kind of business division.

\section{Problem of the study:}

Management accounting techniques play a prominent role in the decision-making process that has an impact on SMEs, which in turn affect the national economy because its importance in providing jobs, as well as 
providing the production and services. The problem of the study is to identify the effectiveness of management accounting techniques on small and mediumsized enterprises and to help the owners or managers to become pilot projects.

\section{Objectives of the study:}

The study aims to see enterprises in Jordan efficiently use managerial accounting techniques (MAT) to help managers with information relevant to decision making. In a broader context, it is planned:

To evaluate the functions of Managerial Accounting Techniques on the decision support system.

To examine how technology impacts on managerial accounting techniques.

To measure the effect of the financial controlling system on advanced managerial accounting techniques.

\section{Hypotheses of the study:}

In the light of the research problem and research objectives, the following hypotheses are formulated.

$\mathrm{H}_{1}$ : Managerial Accounting Techniques functions have significant impact on the decision-support system. techniques.

$\mathrm{H}_{2}$ : Technology has a significant impact on Management Accounting

$\mathrm{H}_{3}$ : Financial controlling system has significant impact on Managerial Accounting Techniques.

\section{Research Methodology:}

Research methodology utilized for this examination, the sources and strategies for information gathering, and the limitations and issues that have been researched. Methodological and philosophical suppositions in view of the distinctive systems for this exploration will be considered, surveyed and supported. There are a few strategies that could be utilized and the significance of methodological ways to deal with consider managerial techniques and decision support system in SMEs. In parliamentary law to accomplish the exploration destinations; the suitable logical technique ought to be embraced. So that, the outcomes and decisions about the exploration topic could be taken out. All things considered, this examination contemplate begins with the research statement, joined by the improvement and figuring the research hypotheses, development of the questionnaire, primary data gathering, analyzing, interpretation ends with getting results and ends about the research subject matter. The sample consisted of 100 SMEs from Amman, capital of Jordan. The data were collected from the managers and employees of SMEs by survey method. The prediction variables are made according to the research 
hypotheses and are designed in a closed structure questionnaire of five-point Likert hierarchy scale. This method was taken to indicate the number of events for each option chosen by the respondents on the same prediction variable. Each respondent was allowed to take only one single questionnaire, the director has entered into a manager and the employee has entered into an employee. The analytical process of quantitative primary data is a statistical analysis of software systems using SPSS. The total distribution of one hundred and six questionnaires was distributed in these firms to be filled with total numbers of their managers ( 72 Questionnaires in medium enterprises and 34 questionnaires in small enterprises). The researcher attained back 100 filled questionnaires from managers; 70/72 (medium $=97 \%$ ) and 30/34 (small $=88 \%$ ). two hundred and twenty-eight questionnaires were distributed on basis of strata in these firms to be filled by total numbers of their employees (160 Questionnaires in medium enterprises and 68 questionnaires in small enterprises). The researcher obtained 200 filled questionnaires from employees; 142/160 (medium=89\%) and 58/68 (small=85\%). Consequently, the appropriate research method followed in this work. That is quantitative in nature based on the close-ended structured questionnaire of five point Likert Scale (Strongly agree $=5$ to strongly disagree $=1$ ) used by Ahmad, (2012) with some modification. The use of Cronbach Alpha coefficient, has reached the degree of reliability for MAT (73\%), for advanced technology (73.7\%), and for the financial controlling system was (78.9\%), which is an acceptable of the reliability rate in order to spread of research results.

\section{Findings and Result:}

This part of findings divided into two parts, first part a multiple hierarchical regression that was conducted to control the influence of moderation of variables on the decision support system (DSS). For this purpose, an independent sample of T-test and ANOVA was performed. To obtain deep differences in the groups, the Tukey HSD test was also used. In the second part, a Structural Equation Modelling Technique (PLS-SEM) was used to validate the conceptual model. The Statistical Package for Social Sciences (SPSS) version 21.0 was used for all these tests.

Table 1: Managerial accounting techniques in managers to predict level of Decision Support System, after controlling for the influence of demographics in SMEs

\begin{tabular}{|c|c|c|c|c|c|}
\hline \multicolumn{6}{|c|}{ Model Summary } \\
\hline Model & $\mathrm{R}$ & R Square & $\begin{array}{l}\text { Adjusted } \\
\text { Square }\end{array}$ & $\mathrm{R}$ & $\begin{array}{l}\text { Std. Error of the } \\
\text { Estimate }\end{array}$ \\
\hline 1 & $.252^{\mathrm{a}}$ & .064 & .024 & & 4.48078 \\
\hline 2 & $.257^{\mathrm{b}}$ & .066 & .016 & & 4.49884 \\
\hline
\end{tabular}




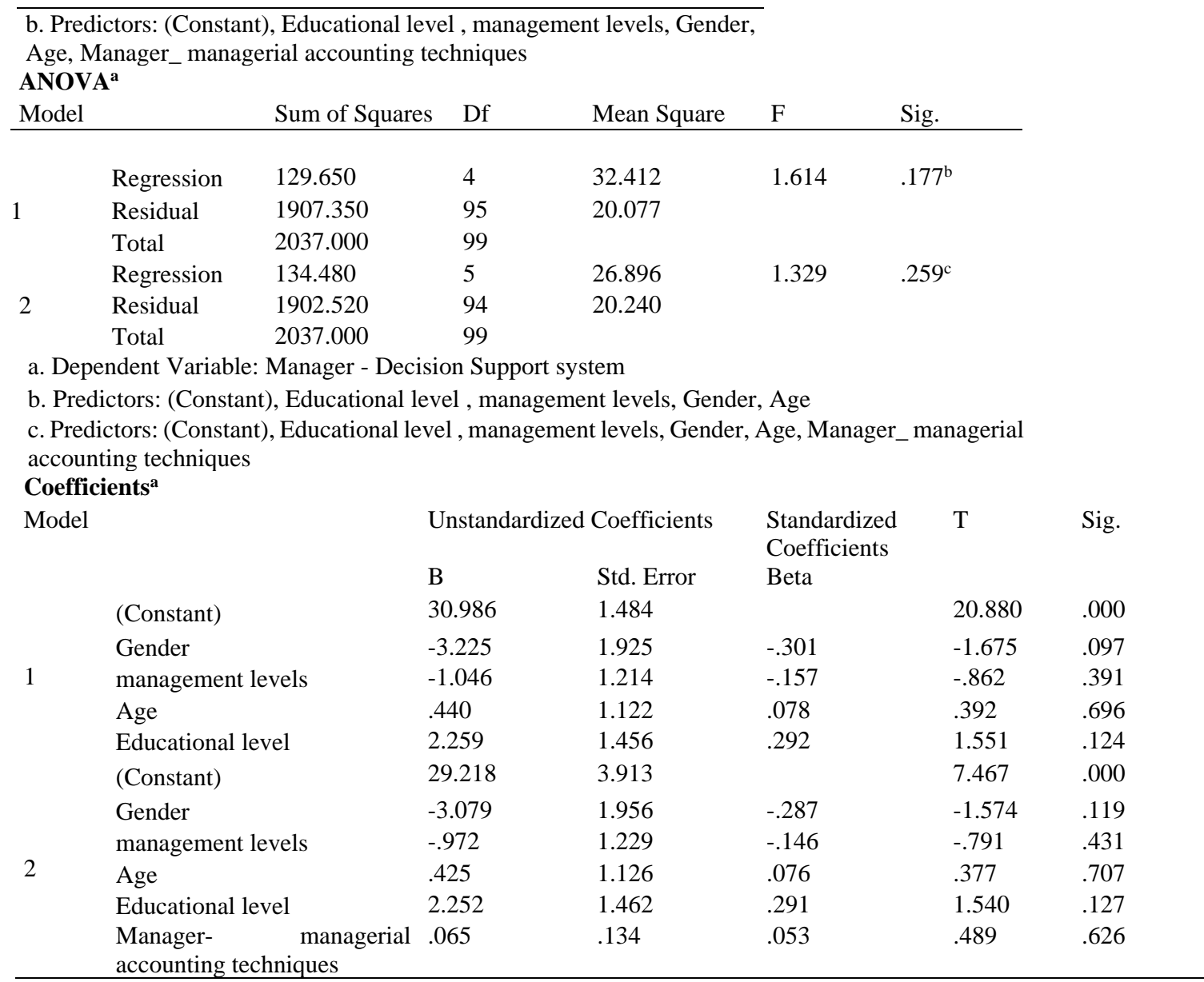

a. Dependent Variable: Manager_Decision Support system

Reports that a hierarchical multiple regression was used to assess the ability of one control measure (managerial accounting techniques in managers) predicting the decision support levels, after checking the impact of demographics. Education Level, Management Level, Gender, Age were entered in the first step, explaining 6.4\% of the variance in Decision Support System, $\mathrm{F}=1.614, \mathrm{p}<.177$. Gender and Management level recorded statistically significant t-test value ( $\mathrm{t}$-test $=-1.675$, and $\mathrm{t}$-test $=-.86 \ldots$ respectively). As shown in above table, there is no significant difference in the impact of demographics on control measure as the levels of probability (p) is $(.097, .391, .696, .124$ respectively), which is more than the significance level of 0.05. After the Managerial Accounting Techniques was entered in step 2, the total variance explained by the model as a whole was $6.6 \%$., F $(4,95)=$ $1.329, \mathrm{p}<.259$. The one control measures explained an additional of $.2 \%$ of the decision-making variance, after demographic control, R-Squared change 
$=.020$. Moreover, as shown in above table, there is no significant difference in the impact of (Gender, Management Level, Age, Educational level) on control measure as the levels of probability $(\mathrm{p})$ is $(.119, .431, .707, .127$ respectively), which is more than the significance level of 0.05 .

In the second model, control measure was statistically not significant recording to $t$-test value $(\mathrm{t}$-test $=0.489)$ as the levels of probability $(\mathrm{p})$ is $(.626)$ which is more than the significance level of 0.05 .

Table 2: Managerial accounting techniques in employees to predict level of Decision Support System, after controlling for the influence of demographics in SMEs

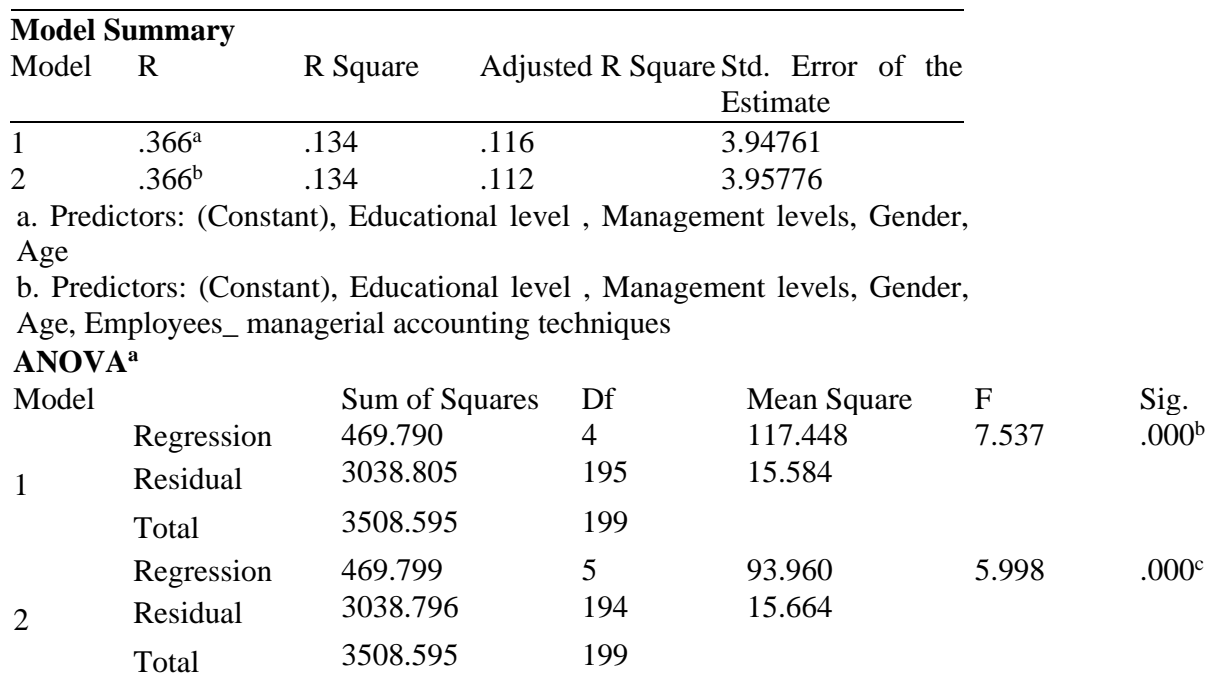

a. Dependent Variable: Employees_Decision support system

b. Predictors: (Constant), Educational level, Management levels, Gender, Age

c. Predictors: (Constant), Educational level , Management levels, Gender, Age, Employees_Advanced managerial accounting tecniques

Coefficients'

Model

Unstandardized Coefficients

(Constant)

Gender

1

Management levels

Age

Educational level

(Constant)

Gender

2

$$
\text { Management levels }
$$

Age

Educational level

Employees_ accounting techniques

\section{B}

36.495

$-1.879$

$-3.076$

.816

2.367

36.546

$-1.878$

$-3.075$

.819

2.364

managerial-.002

7
9
6
6
8
5
5

Std. Error
1.665
1.659
.744
.753
1.445
2.663
1.664
.746
.770
1.452
.100

Standardized

$\mathrm{T}$

Coefficients

Beta

21.917

$-.197$

$-.464$

.188

.264

$-1.133$

$-4.134$

1.083

1.638

13.722

$-.197$

$-.464$

.189

.263

$-.002$

$-1.129$

$-4.123$

1.063

1.628

$-.024$

.000

Sig.

a. Dependent Variable: Employees_ Decision support system 
Reports that a hierarchical multiple regression was used to assess the ability of one control measure (Advanced managerial accounting techniques in employees) to predict levels of Decision Support System, after controlling for the influence of demographics. Demographics (Educational level, management levels, Gender, Age) were entered at first step, explaining 13.4\% of the variance in Decision Support System. Gender, Management level, Age, Education were statistically significant recording a $\mathrm{t}$-test value ( $\mathrm{t}$-test $=-1.13$, $\mathrm{t}$-test $=-4.13$, $\mathrm{t}$-test $=1.08, \mathrm{t}$-test $=1.64$ respectively). As shown in above table, there is no significant difference in the impact of (Gender, Age, Educational level) on control measure as the levels of probability (p) is $(.259, .280, .103$ respectively), which is more than the significance level of 0.05 . In contrast, there is a significant difference in the impact of (Management level) on control measure as the levels of probability (p) is (.000), which is less than the significance level of 0.05 .

After entering Advanced Managerial Accounting Techniques at step 2 the total variance explained by the model as a whole was $13.4 \%$., F $(4,195)$ $=5.998, \mathrm{p}<.000$. Moreover, as shown in above table, there is no significant difference in the impact of Gender, Age, Educational level) on control measure as the levels of probability (p) is $(.260, .289, .105$ respectively), which is more than the significance level of 0.05 . In contrast, there is a significant difference in the impact of (Management level) on control measure as the levels of probability (p) is (.000), which is less than the significance level of 0.05 .

The one control measures explained an additional of $13.4 \%$ of the variance in Decision Support System, after controlling for Demographics, $\mathrm{R}$ squared change $=.000$. In the second model, control measure was statistically insignificant recording a t-test value ( $\mathrm{t}$-test $=-.024)$ as the levels of probability (p) is (.981) which is more than the significance level of 0.05.

The findings of the research accept the research hypothesis, H.1. The managerial accounting techniques impact in decision making process.

Table 3: Use of Technology in managers to predict level of Decision Support System, after controlling for the influence of demographics in SMEs

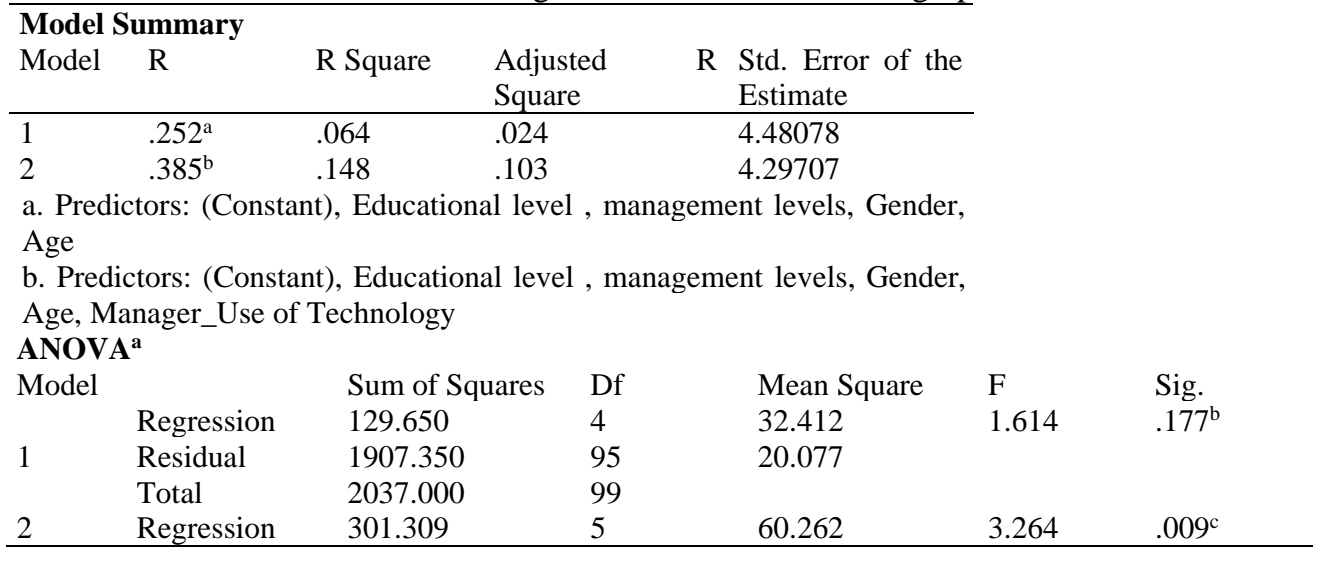




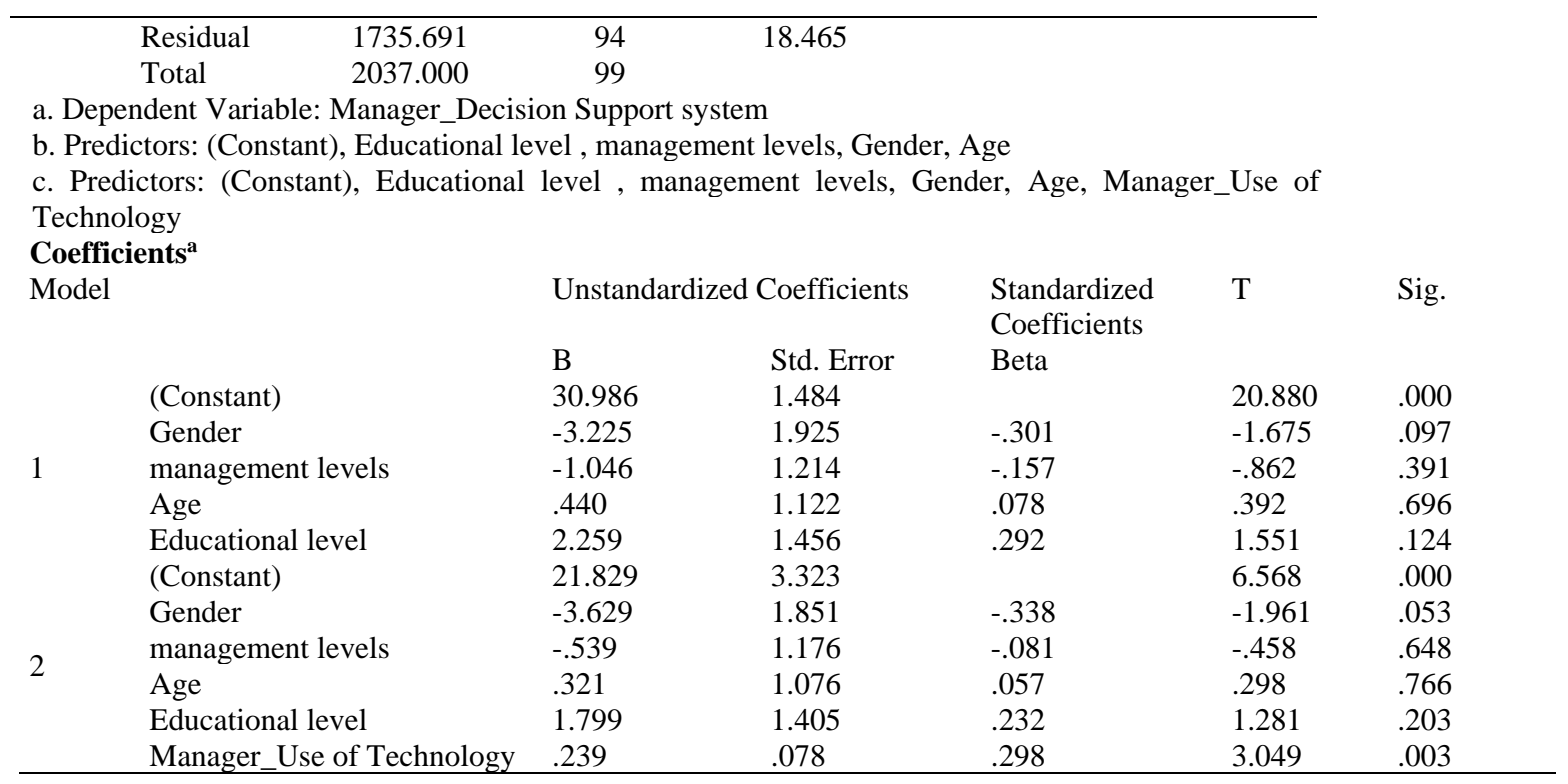

a. Dependent Variable: Manager_Decision Support system

Reports that a hierarchical multiple regression was used to assess the ability of one control measure (Use of Technology) predicting the decision support levels, after checking the impact of demographics. Education Level, Management Level, Gender, Age were entered in the first step, explaining $6.4 \%$ of the variance in Decision Support System. Gender and Management level recorded statistically significant $t$-test value $(\mathrm{t}$-test $=-1.675$, and $\mathrm{t}$-test $=$ .86 respectively). As shown in above table, there is no significant difference in the impact of (Gender, Management Level, Age, Educational level) on control measure as the levels of probability (p) is $(.097, .391, .696, .124$ respectively), which is more than the significance level of 0.05 . After the Use of Technology was entered in step 2, the total variance explained by the model as a whole $15 \%$., $\mathrm{F}(4,95)=4.333, \mathrm{p}<.001$. Moreover, as shown in above table, there is no significant difference in the impact of (Gender, Management Level, Age, Educational level) on control measure as the levels of probability (p) is $(.053, .648, .766, .203$ respectively), which is more than the significance level of 0.05 .

The one control measures explained an additional about $8 \%$ of the decision-making variance, after demographic control, R-Squared change $=.084$. In the second model, control measure was statistically significant recording ( $\mathrm{t}$-test $=1.6)$ as the levels of probability $(\mathrm{p})$ is $(.003)$ which is less than the significance level of 0.05 . 
Table 4: Use of Technology in employees to predict level of Decision Support System, after controlling for the influence of demographics in SMEs

\begin{tabular}{lllll}
\hline \multicolumn{2}{l}{ Model Summary } & & & \\
Model & $\mathrm{R}$ & R Square & $\begin{array}{l}\text { Adjusted } \\
\text { Square }\end{array}$ & $\begin{array}{c}\text { RStd. Error of the } \\
\text { Estimate }\end{array}$ \\
\hline 1 & $.366^{\mathrm{a}}$ & .134 & .116 & 3.94761 \\
2 & $.366^{\mathrm{b}}$ & .134 & .112 & 3.95777
\end{tabular}

a. Predictors: (Constant), Educational level , Management levels, Gender, Age

b. Predictors: (Constant), Educational level , Management levels, Gender, Age, Employees_Use of technology

\section{ANOVA $^{\mathrm{a}}$}

$\begin{array}{lllllll}\text { Model } & & \text { Sum of Squares } & \text { df } & \text { Mean Square } & \text { F } & \text { Sig. } \\ & \text { Regression } & 469.790 & 4 & 117.448 & 7.537 & .000^{b} \\ 1 & \text { Residual } & 3038.805 & 195 & 15.584 & & \\ & \text { Total } & 3508.595 & 199 & & & \\ & \text { Regression } & 469.793 & 5 & 93.959 & 5.998 & .000^{\mathrm{c}} \\ 2 & \text { Residual } & 3038.802 & 194 & 15.664 & & \\ & \text { Total } & 3508.595 & 199 & & & \end{array}$

a. Dependent Variable: Employees_Decision support system

b. Predictors: (Constant), Educational level, Management levels, Gender, Age

c. Predictors: (Constant), Educational level, Management levels, Gender, Age, Employees_Use of technology

Coefficients ${ }^{\mathrm{a}}$

Model

\begin{tabular}{|c|c|c|c|c|c|}
\hline & \multicolumn{2}{|c|}{ Unstandardized Coefficients } & $\begin{array}{l}\text { Standardized } \\
\text { Coefficients }\end{array}$ & $\mathrm{T}$ & Sig. \\
\hline & B & Std. Error & Beta & & \\
\hline nstant) & 36.495 & 1.665 & & 21.917 & .000 \\
\hline der & -1.879 & 1.659 & -.197 & -1.133 & .259 \\
\hline lagement levels & -3.076 & .744 & -.464 & -4.134 & .000 \\
\hline & .816 & .753 & .188 & 1.083 & .280 \\
\hline cational level & 2.367 & 1.445 & .264 & 1.638 & .103 \\
\hline sstant) & 36.462 & 2.902 & & 12.566 & .000 \\
\hline der & -1.882 & 1.675 & -.197 & -1.124 & .263 \\
\hline agement levels & -3.074 & .759 & -.464 & -4.050 & .000 \\
\hline & .814 & .760 & .188 & 1.071 & .285 \\
\hline ational level & 2.369 & 1.459 & .264 & 1.623 & .106 \\
\hline oyees_Use & of.001 & .054 & .001 & .014 & .989 \\
\hline
\end{tabular}

a. Dependent Variable: Employees_Decision support system

Reports that a hierarchical multiple regression was used to assess the ability of one control measure (Use of Technology in employees) to predict levels of Decision Support System, after controlling for the influence of demographics. Demographics (Educational level, management levels, Gender, Age) were entered at first step, explaining $13.4 \%$ of the variance in Decision Support System. Gender, Management level, Age, Education were statistically significant recording a t-test value ( $\mathrm{t}$-test $=-1.1$, $\mathrm{t}$-test $=-4.13, \mathrm{t}$ test $=1.1$, $\mathrm{t}$-test $=1.6$ respectively). As shown in above table, there is no 
significant difference in the impact of (Gender, Age, Educational level) on control measure as the levels of probability (p) is $(.259, .280, .103$ respectively), which is more than the significance level of 0.05 . In contrast, there is a significant difference in the impact of (Management level) on control measure as the levels of probability (p) is (.000), which is less than the significance level of 0.05 .

After entering Use of Technology at step 2 the total variance explained by the model as a whole was $13.4 \%$., F (4, 195) = 5.998, p<.000. Moreover, as shown in above table, there is no significant difference in the impact of Gender, Age, Educational level) on control measure as the levels of probability (p) is $(.263, .285, .106$ respectively), which is more than the significance level of 0.05 . In contrast, there is a significant difference in the impact of (Management level) on control measure as the levels of probability (p) is (.000), which is less than the significance level of 0.05 .

The one control measures explained an additional of .00\% of the variance in Decision Support System, after controlling for Demographics, $\mathrm{R}$ squared change $=.000$. In the second model, control measure was statistically insignificant recording a t-test value $(\mathrm{t}$-test $=.014)$, as the levels of probability (p) is (.989) which is more than the significance level of 0.05 .

The findings of the research accept the research hypothesis, H.2. The use of technology has significantly contributed in advanced managerial accounting techniques towards the decision making process.

Table 5: Financial controlling system in managers to predict level of Decision Support System, after controlling for the influence of demographics in SMEs

\begin{tabular}{|c|c|c|c|c|c|c|c|c|}
\hline \multicolumn{9}{|c|}{ Model Summary } \\
\hline Model & $\mathrm{R}$ & R Square & \multicolumn{2}{|c|}{$\begin{array}{l}\text { Adjusted } \\
\text { Square }\end{array}$} & $\begin{array}{l}\text { Std. Error of th } \\
\text { Estimate }\end{array}$ & & & \\
\hline 1 & $.252^{\mathrm{a}}$ & .064 & \multicolumn{2}{|c|}{.024} & 4.48078 & & & \\
\hline 2 & $.374^{\mathrm{b}}$ & .140 & \multicolumn{2}{|l|}{.094} & 4.31647 & & & \\
\hline \multirow{2}{*}{\multicolumn{9}{|c|}{$\begin{array}{l}\text { a. Predictors: (Constant), Educational level , management levels, } \\
\text { Gender, Age } \\
\text { b. Predictors: (Constant), Educational level , management levels, } \\
\text { Gender, Age, Manager_Financial controlling system } \\
\text { ANOVA }\end{array}$}} \\
\hline & & & & & & & & \\
\hline \multirow[t]{2}{*}{ Model } & & Sum of $S$ & quares & Df & Mean Square & $\mathrm{F}$ & Sig. & \\
\hline & Regression & 129.650 & & 4 & 32.412 & 1.614 & $.177^{\mathrm{b}}$ & \\
\hline \multirow[t]{3}{*}{1} & Residual & 1907.350 & & 95 & 20.077 & & & \\
\hline & Total & 2037.000 & & 99 & & & & \\
\hline & Regression & 285.597 & & 5 & 57.119 & 3.066 & $.013^{\mathrm{c}}$ & \\
\hline \multirow[t]{2}{*}{2} & Residual & 1751.403 & & 94 & 18.632 & & & \\
\hline & Total & 2037.000 & & 99 & & & & \\
\hline \multicolumn{9}{|c|}{$\begin{array}{l}\text { a. Dependent Variable: Manager_Decision Support system } \\
\text { b. Predictors: (Constant), Educational level, management levels, Gender, Age } \\
\text { c. Predictors: (Constant), Educational level , management levels, Gender, Age, Manager_ } \\
\text { Financial controlling system } \\
\text { Coefficients' }\end{array}$} \\
\hline \multicolumn{2}{|l|}{ Model } & \multicolumn{4}{|c|}{ Unstandardized Coefficients } & $\begin{array}{l}\text { Standardized } \\
\text { Coefficients }\end{array}$ & $\mathrm{T}$ & Sig. \\
\hline
\end{tabular}




\begin{tabular}{|c|c|c|c|c|c|c|}
\hline & & $\mathrm{B}$ & Std. Error & Beta & & \\
\hline \multirow{6}{*}{1} & (Constant) & 30.986 & 1.484 & & 20.880 & .000 \\
\hline & Gender & -3.225 & 1.925 & -.301 & -1.675 & .097 \\
\hline & management levels & -1.046 & 1.214 & -.157 & -.862 & .391 \\
\hline & Age & .440 & 1.122 & .078 & .392 & .696 \\
\hline & Educational level & 2.259 & 1.456 & .292 & 1.551 & .124 \\
\hline & (Constant) & 20.951 & 3.751 & & 5.585 & .000 \\
\hline \multirow{5}{*}{2} & Gender & -2.875 & 1.858 & -.268 & -1.547 & .125 \\
\hline & management levels & -.760 & 1.174 & -.114 & -.647 & .519 \\
\hline & Age & .448 & 1.080 & .080 & .414 & .680 \\
\hline & Educational level & 1.222 & 1.448 & .158 & .844 & .401 \\
\hline & $\begin{array}{l}\text { Manager__ Financial } \\
\text { controlling system }\end{array}$ & .251 & .087 & .291 & 2.893 & .005 \\
\hline & ndent Variable: Manager_De & cision $s$ & & & & \\
\hline
\end{tabular}

Reports that a hierarchical multiple regression was used to assess the ability of one control measure (Financial Controlling System) predicting the decision support levels, after checking the impact of demographics. Education Level, Management Level, Gender, Age were entered in the first step, explaining $6.4 \%$ of the variance in Decision Support System. Gender and Management level recorded statistically significant $\mathrm{t}$-test value ( $\mathrm{t}$-test $=-1.7$, and $t$-test $=-.862$ respectively). As shown in above table, there is no significant difference in the impact of (Gender, Management Level, Age, Educational level) on control measure as the levels of probability $(p)$ is $(.097, .391, .696$, .124 respectively), which is more than the significance level of 0.05 .

After the Financial Controlling System was entered in step 2, the total variance explained by the model as a whole $14 \%$, $\mathrm{F}(4,95)=4.333, \mathrm{p}<.001$. Moreover, as shown in above table, there is no significant difference in the impact of (Gender, Management Level, Age, Educational level) on control measure as the levels of probability $(\mathrm{p})$ is $(.125, .519, .680, .401$ respectively), which is more than the significance level of 0.05 .

The one control measures explained an additional about $8 \%$ of the decision-making variance, after demographic control, R-Squared change $=.076$. In the second model, control measure recoded ( $\mathrm{t}$-test $=2.89$ ), as the levels of probability (p) is (.005) which is equal the significance level of 0.05 .

Table 6: Financial Controlling System in employees to predict level of Decision Support System, after controlling for the influence of demographics in SMEs

\begin{tabular}{|c|c|c|c|c|}
\hline \multicolumn{5}{|c|}{ Model Summary } \\
\hline Model & $\mathrm{R}$ & R Square & Adju & $\begin{array}{l}\text { reStd. Error of the } \\
\text { Estimate }\end{array}$ \\
\hline 1 & $.366^{\mathrm{a}}$ & .134 & .116 & 3.94761 \\
\hline 2 & $.392^{\mathrm{b}}$ & .154 & .132 & 3.91233 \\
\hline \multicolumn{5}{|c|}{$\begin{array}{l}\text { a. Predictors: (Constant), Educational level, Management levels, Gender, } \\
\text { Age }\end{array}$} \\
\hline
\end{tabular}




\begin{tabular}{lllllll}
\hline Model & & Sum of Squares & Df & Mean Square & F & Sig. \\
& Regression & 469.790 & 4 & 117.448 & 7.537 & $.000^{\mathrm{b}}$ \\
1 & Residual & 3038.805 & 195 & 15.584 & & \\
& Total & 3508.595 & 199 & & & \\
& Regression & 539.161 & 5 & 107.832 & 7.045 & $.000^{\mathrm{c}}$ \\
2 & Residual & 2969.434 & 194 & 15.306 & &
\end{tabular}
a. Dependent Variable: Employees_Decision support system
b. Predictors: (Constant), Educational level, Management levels, Gender, Age
c. Predictors: (Constant), Educational level, Management levels, Gender, Age, Employees_Financial
Controlling System

\section{Coefficients}

Model

Unstandardized Coefficients

Standardized

Sig.

$\begin{array}{llll} & & \\ & & \text { B } & \text { Std. Error } \\ & & 36.495 & 1.665 \\ & \text { (Constant) } & -1.879 & 1.659 \\ & \text { Gender } & -3.076 & .744 \\ & \text { Management levels } & .816 & .753 \\ & \text { Age } & 2.367 & 1.445 \\ & \text { Educational level } & 30.985 & 3.070 \\ \text { (Constant) } & -2.747 & 1.694 \\ & \text { Gender } & -3.079 & .737 \\ & \text { Management levels } & .824 & .746 \\ \text { Age } & 2.658 & 1.438 \\ \text { Educational level } & \text { Financial.152 } & .071 \\ \text { Employees_- } & & \\ \text { Controlling System } & & \\ \end{array}$

Coefficients

Beta

$\begin{array}{lll} & 21.917 & .000 \\ -.197 & -1.133 & .259 \\ -.464 & -4.134 & .000 \\ .188 & 1.083 & .280 \\ .264 & 1.638 & .103 \\ & 10.094 & .000 \\ -.288 & -1.622 & .106 \\ -.465 & -4.176 & .000 \\ .190 & 1.104 & .271 \\ .296 & 1.848 & .066\end{array}$

$\begin{array}{lll}.154 & 2.129 & .035\end{array}$

a. Dependent Variable: Employees__ Decision support system

Reports that a hierarchical multiple regression was used to assess the ability of one control measure (Financial Controlling System in employees) to predict levels of Decision Support System, after controlling for the influence of demographics. Demographics (Educational level, management levels, Gender, Age) were entered at first step, explaining $13.4 \%$ of the variance in Decision Support System. Gender, Management level, Age, Education were statistically significant recording a t-test value $(\mathrm{t}$-test $=-1.13$, $\mathrm{t}$-test $=-4.134, \mathrm{t}$ test $=1.1$, $\mathrm{t}$-test $=1.6$ respectively). As shown in above table, there is no significant difference in the impact of (Gender, Age, Educational level) on control measure as the levels of probability (p) is $(.259, .280, .103$ respectively), which is more than the significance level of 0.05 . In contrast, there is a significant difference in the impact of (Management level) on control measure as the levels of probability (p) is (.000), which is less than the significance level of 0.05 .

After entering Financial Controlling System at step 2 the total variance explained by the model as a whole was $15.4 \%$., $\mathrm{F}(4,195)=7.045, \mathrm{p}<.000$. Moreover, as shown in above table, there is no significant difference in the impact of Gender, Age, Educational level) on control measure as the levels of probability $(\mathrm{p})$ is $(.106, .271, .066$ respectively), which is more than the 
significance level of 0.05 . In contrast, there is a significant difference in the impact of (Management level) on control measure as the levels of probability (p) is (.000), which is less than the significance level of 0.05.

The one control measures explained an additional of $2 \%$ of the variance in Decision Support System, after controlling for Demographics, $R$ squared change $=.02$. In the second model, control measure was statistically insignificant recording a t-test value (t-test $=2.129)$, as the levels of probability (p) is (.035) which is less than the significance level of 0.05 . The findings of the research accept the research hypothesis H.3. The financial controlling system has significantly contributed in managerial accounting techniques towards the decision making process.

\section{Second Part:}

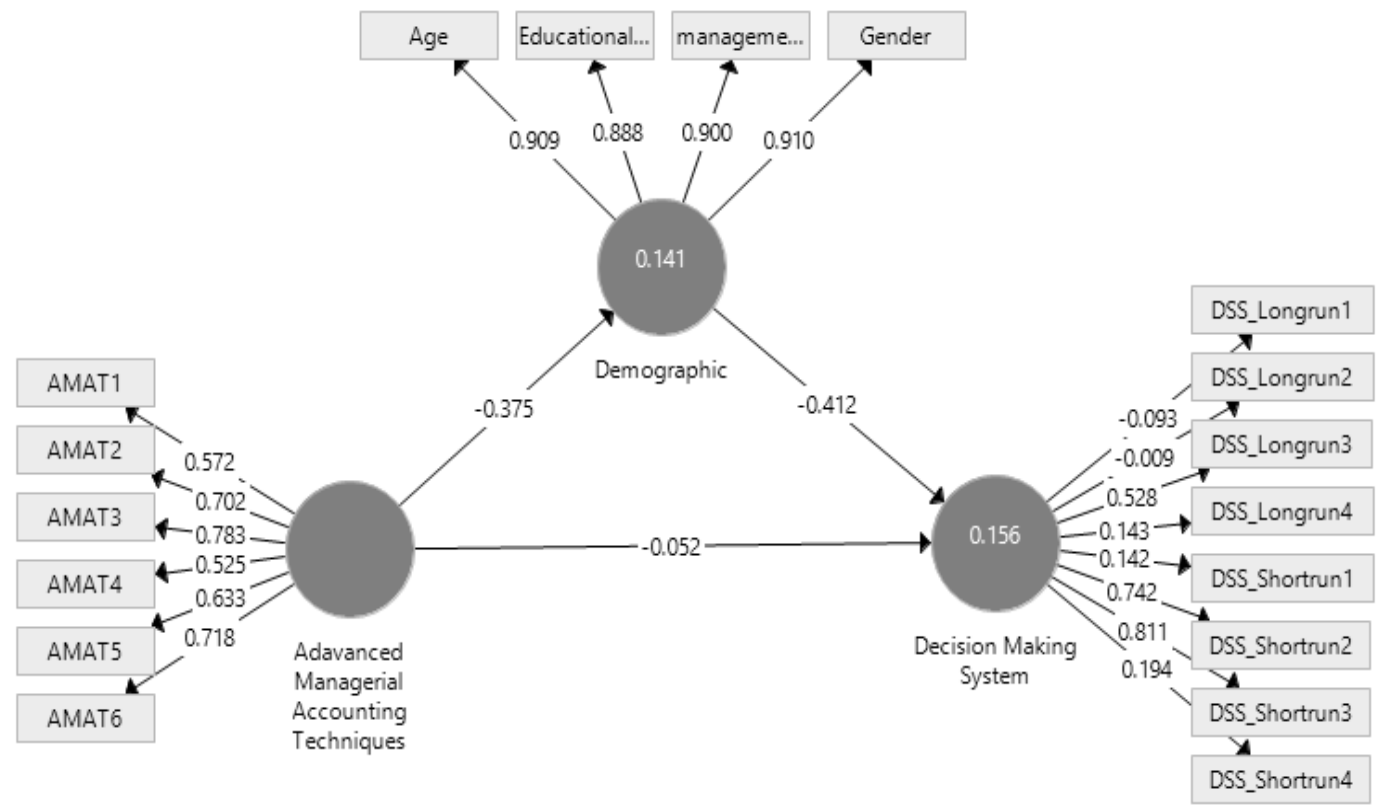

Figure 1. Contribution of Demographics Variables and Advanced Managerial Accounting

Techniques of Managers in Decision Making System in SMEs in Amman, Jordan.

The figure 1 shows that demographic variables (age, educational level, management level and gender) were the significant contributors of decision making system of managers in SMEs in Amman, Jordan, $\beta=-0.412$. The advanced managerial accounting techniques also contributed in decision making system, $\beta=-0.052$. Whereas, Demographic variables contributed more as compared to advanced managerial accounting techniques in decision making system of SMEs. In the outer loading factors, the age $\mathrm{r}=0.909$, and AMAT (measuring and evaluating performance) $r=0.783$ were the most contributed factors in the decision making system. 


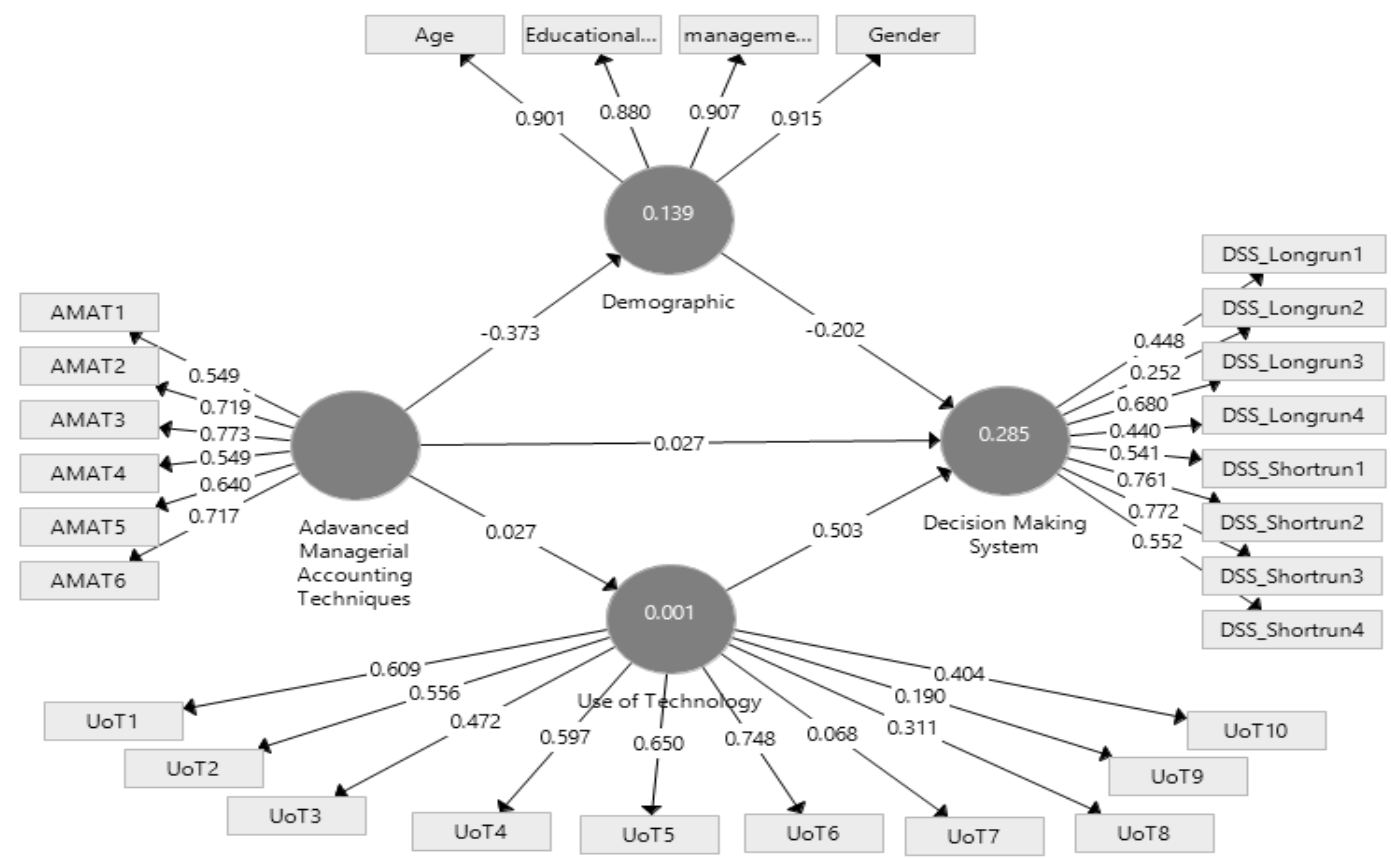

Figure 2. Contribution of Demographics Variables, Use of Technology, and Advanced Managerial Accounting Techniques of Managers in Decision Making System in SMEs in Amman, Jordan.

The figure 2 shows that variations were observed when use of technology was added in the model. The level of decision making system in managers was enhanced from 0.156 to 0.285 . The contribution of demographic variables (age, school, and gender) were raised in decision making system, $\beta=-0.202$ and advanced managerial accounting techniques significantly contributed in demographic variables, $\beta=-0.373$. Whereas, use of technology more contributed to decision making system $\beta=0.503$ as compared to advanced managerial accounting techniques to decision making system $\beta=0.027$. In the outer loading factors, gender $\mathrm{r}=0.915$, AMAT (measuring and evaluating performance) $\mathrm{r}=0.773$, use of technology 6 (technology helps companies change business by allowing them to use new methods) $\mathrm{r}=0.748$ were the most significant factors observed in decision making system. 


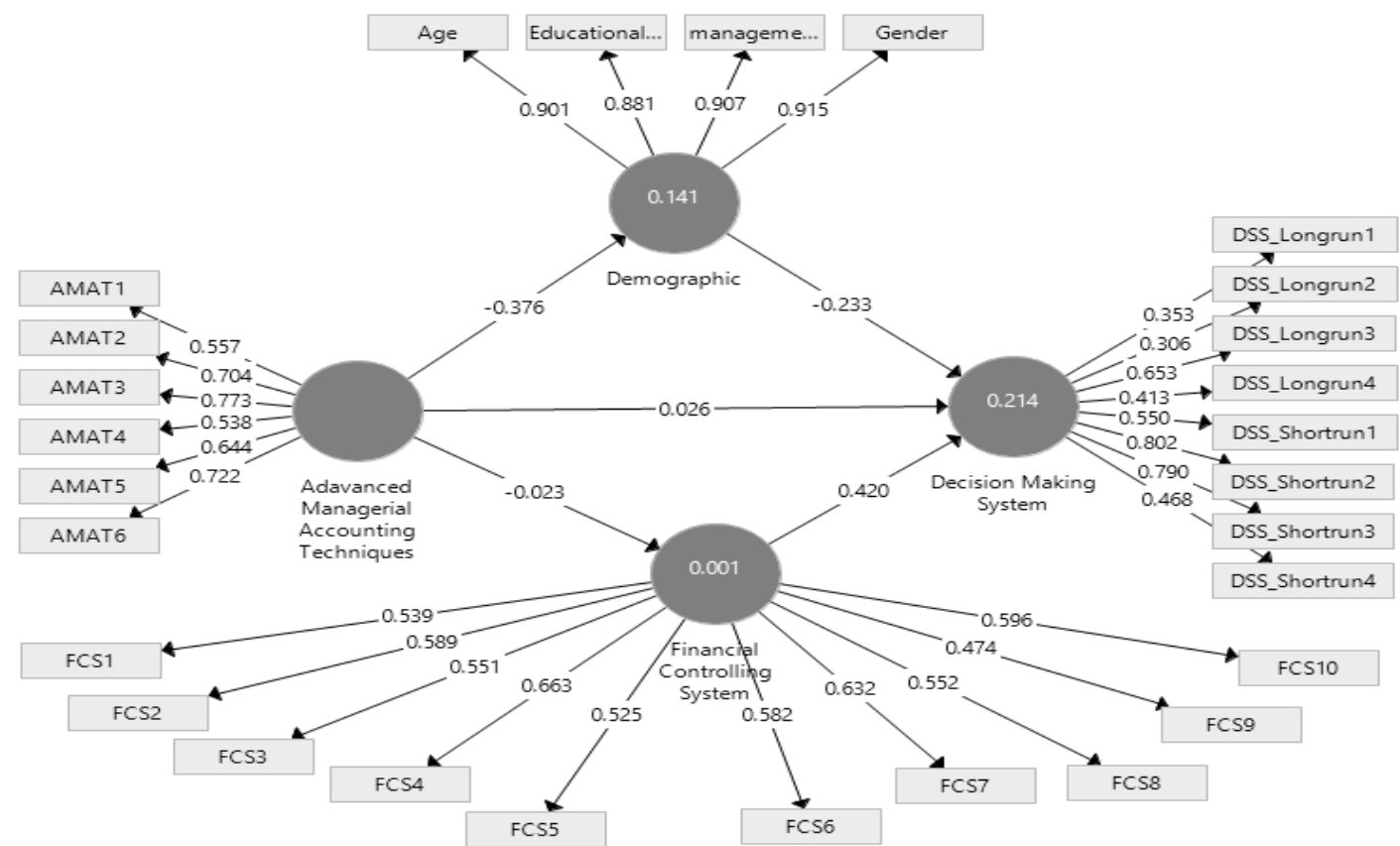

Figure 3. Contribution of Demographics Variables, Financial controlling system, and Advanced Managerial Accounting Techniques of Managers in Decision Making System in SMEs in Amman, Jordan.

The figure 3 shows that variations were observed when financial controlling system was added in the model. The level of decision making system in managers was enhanced from 0.156 to 0.214 . The contribution of demographic variables were raised in decision making system, $\beta=-0.233$ and advanced managerial accounting techniques significantly contributed in demographic variables, $\beta=-0.376$. Whereas, financial controlling system more contributed to decision making system $\beta=0.420$ as compared to advanced managerial accounting techniques to decision making system $\beta=0.026$. In the outer loading factors, gender $\mathrm{r}=0.915$, AMAT (measuring and evaluating performance) $\mathrm{r}=0.773$, financial controlling system (process controlling), $\mathrm{r}=0.663$ were the most significant factors observed in decision making system. 


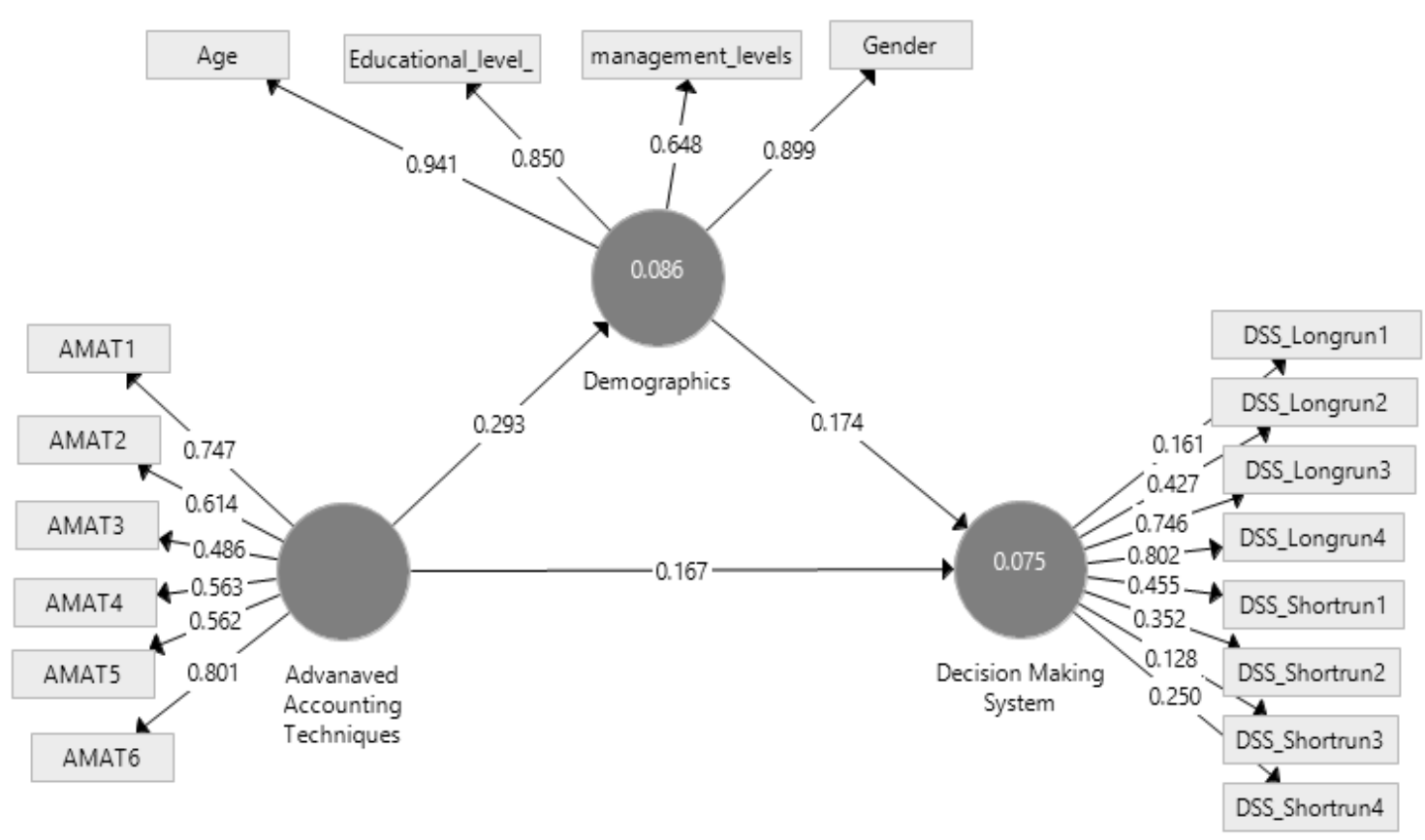

Figure 4. Contribution of Demographics Variables, and Advanced Managerial Accounting Techniques of Employees in Decision Making System in SMEs in Amman, Jordan.

The figure 4 shows that demographic variables (age, educational level, management level and gender) were the significant contributors of decision making system of employees in SMEs in Amman, Jordan, $\beta=0.174$. The advanced managerial accounting techniques also contributed in decision making system, $\beta=0.167$. Whereas, Demographic variables contributed more as compared to advanced managerial accounting techniques in decision making system of SMEs. In the outer loading factors, the age $\mathrm{r}=0.941$, and AMAT (improving internal and external communication) $r=0.783$ were the most contributed factors in the decision making system. 


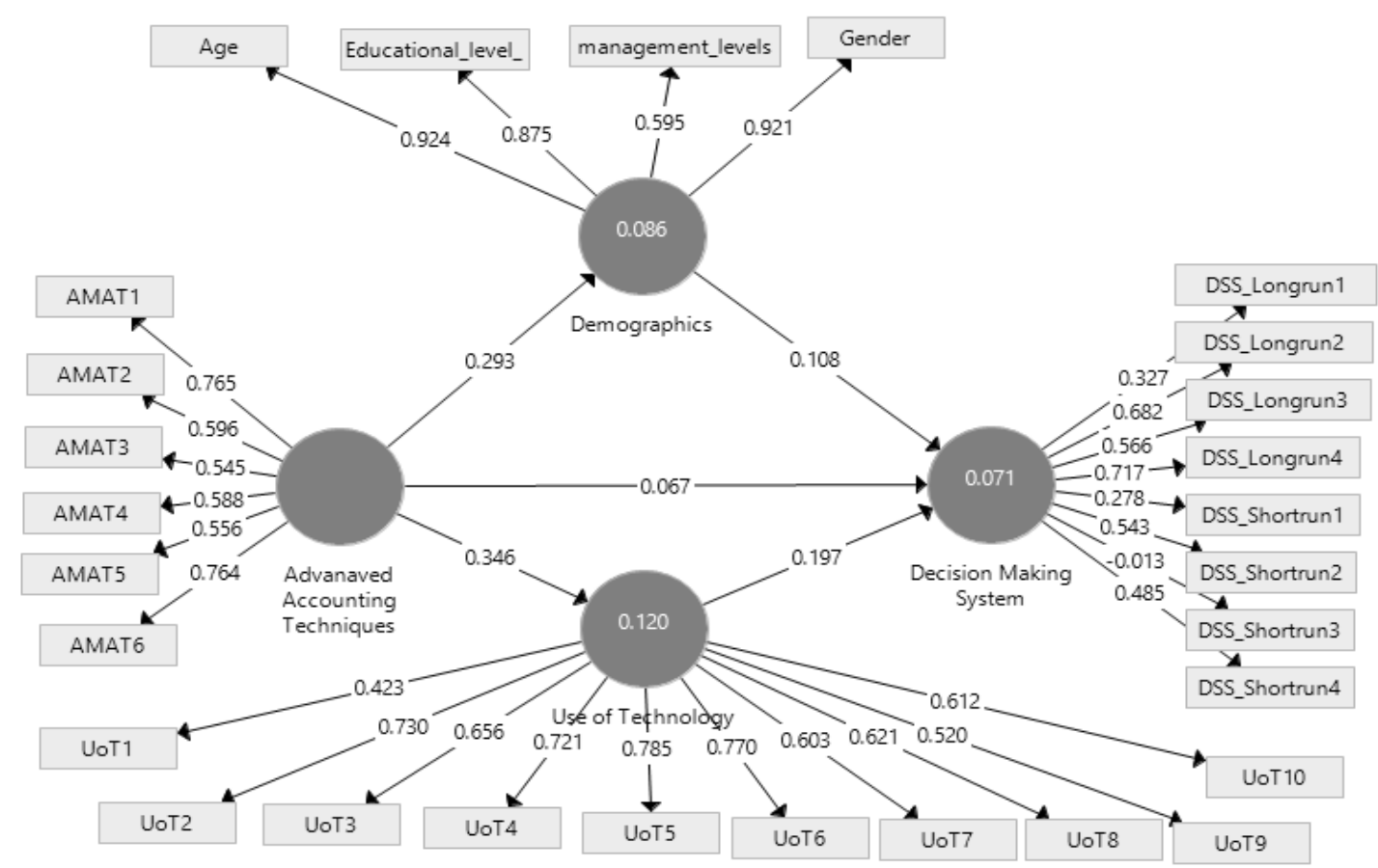

Figure 5. Contribution of Demographics Variables, Use of Technology and Advanced Managerial Accounting Techniques of Employees in Decision Making System in SMEs in Amman, Jordan.

The figure 5 shows that variations were observed when use of technology was added in the model. The level of decision making system in employees was enhanced from 0.075 to 0.103 . The contribution of demographic variables (age, school, and gender) were raised in decision making system, $\beta=0.108$ and advanced managerial accounting techniques significantly contributed in demographic variables, $\beta=0.293$. Whereas, use of technology more contributed to decision making system $\beta=0.197$ as compared to advanced managerial accounting techniques to decision making system $\beta=$ 0.067. In the outer loading factors, age $\mathrm{r}=0.924$, AMAT (planning the future strategies, tactics, and current activities) $\mathrm{r}=0.765$, use of technology 5 (the technology created facilitate the flow information to development the MAT) $\mathrm{r}=0.785$ were the most significant factors observed in decision making system. 


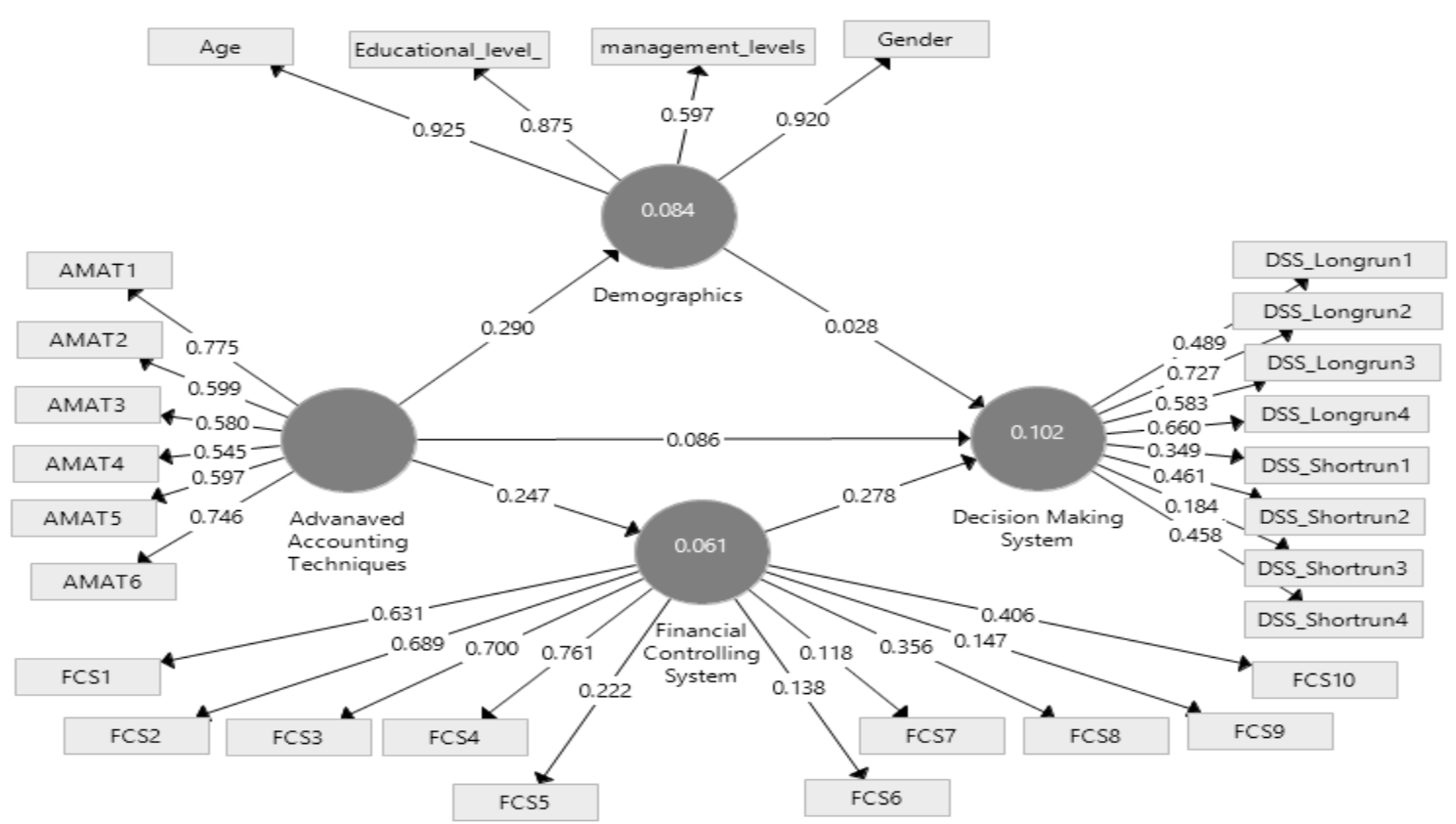

Figure 6. Contribution of Demographics Variables, Financial Controlling System and Advanced Managerial Accounting Techniques of Employees in Decision Making System in SMEs in Amman, Jordan.

The figure 6 shows that variations were observed when financial controlling system was added in the model. The level of decision making system in employees was enhanced from 0.075 to 0.102 . The contribution of demographic variables (age, school, and gender) were raised in decision making system, $\beta=0.028$. Whereas, financial controlling system more contributed to decision making system $\beta=0.278$ as compared to advanced managerial accounting techniques to decision making system $\beta=0.086$. In the outer loading factors, age $\mathrm{r}=0.925$, AMAT (planning future strategies, tactics, and operations $\mathrm{r}=0.775$, financial controlling system (contract controlling) $\mathrm{r}=0.700$ were the most significant factors observed in decision making system.

\section{Conclusion:}

The research affirmed the considerable effects of modern managerial accounting techniques and demographics; gender, management level, age and education on the decision support system in SMEs of Amman. The results of the study were agreed with (Al Mansoor, 2010; Zumlot, 2013), which affirmed on considerable effects of modern managerial accounting techniques on the decision support system in SMEs. In addition, the present research concluded that the importance of the use of technology. The results of the study were agreed with Pepe (2011) which indicate that technology effect strengthened 
administrative accounting capabilities to interpret data efficiently and effectively. The research also established that there was no significant gender, management levels, and age difference in managers working in SMEs in Amman, Jordan on the financial controlling system, but significant on the financial controlling system in employees working in SMEs in Amman, Jordan. Whereas, the education levels were a significant contributor of managers and employees in the financial controlling system on the decision support system. The results of the study were agreed with Al \& McLellan (2011) which indicate that there is significant impact to the financial controlling system on managerial accounting techniques.

It is recommended that:

- The application of accounting management techniques is very important in decision-making with view to survive and expansion in the light of the complex and changing environment.

- The managements of organizations realize the significance of the utilization and application of advanced technology for accomplishing the objectives of these organizations and their prosperity and development in the business sectors.

- The organizations also realize the importance of the financial controlling system, to keep the organization equipped with modern techniques of accounting.

\section{References:}

1. AbdulHussien, H. M., \& Hamza, S. A. D. I. K. (2012). Strategic Management Accounting Techniques in Romanian Companies: An Empirical Study. Studies in Business \& Economics, 7(2).

2. Ahmad, K. (2012). The use of management accounting practices in Malaysian SMEs. Available at: https://ore.exeter.ac.uk/repository/handle/10036/3758.

3. Al Mansoor, J. (2010). Management accounting techniques and requirements of strategic management: available at: http://mtechnicb.alafdal.net/t26-topic [18 September 2010].

4. Al, S. F. A., \& McLellan, J. D. (2011). Management Accounting Practices in Egypt--A Transitional Economy Country. Journal of Accounting, Business \& Management, 18(2).

5. Al-Khfsh, A. (2015). Small and Medium Enterprises challenges and Solutions. Ammon News. Available at: http://www.ammonnews.net/article/226721.

6. Al-Omiri, M., \& Drury, C. (2007). A survey of factors influencing the choice of product costing systems in UK organizations. Management accounting research, 18(4), 399-424. 
7. Al-Sayyed, S. M. (2015). The Impact of the use of Modern Management Accounting Techniques to Streamline Decision-Making in the Jordanian Industrial Companies. Development, 7(10).

8. Bessant, J., \& Tidd, J. (2007). Innovation and entrepreneurship. John Wiley \& Sons.

9. Fajr, Nawaf, al-Dulaimi, \& Khalil. (2012). Accounting industrial costs. International House of scientific publishing and distribution, and the House of Culture for publication and distribution, Amman, Jordan.

10. Harrison, E. F. (1996). A process perspective on strategic decisionmaking. Management decision, 34(1), 46-53.

11. Horngren, C. T., Sundem, G. L., Stratton, W. O., Burgstahler, D., \& Schatzberg, J. (2002). Introduction to Management Accounting. Prentice Hall.

12. Maheshwari, S. N. (1989). Management Accounting for Bankers. Sultan Chand \& Sons.

13. Maina Waweru, N., Hoque, Z., \& Uliana, E. (2004). Management accounting change in South Africa: case studies from retail services. Accounting, Auditing \& Accountability Journal, 17(5), 675704.

14. Maqbool-ur-Rehman, S. (2011). Which Management Accounting Techniques Influence Profitability in the Manufacturing Sector of Pakistan? Book Review, 53.

15. Pepe, A. A. (2011). The evolution of technology for the accounting profession. CPA Practice Advisor, (April). Available at: http://www.cpapracticeadvisor.com/article/10263076/the-evolutionof-technology-for-the-accounting-profession[APR 19, 2011].

16. Prakash, Y., \& Gupta, M. (2008). Exploring the relationship between organization structure and perceived innovation in the manufacturing sector of India. Singapore Management Review, 30(1), 55.

17. Saunders, M. N., \& Thornhill, A. (2011). Researching sensitively without sensitizing: Using a card sort in a concurrent mixed methods design to research trust and distrust. International Journal of Multiple Research Approaches, 5(3), 334-350.

18. Solomon. (2015). the role of Small and Medium Enterprises in Jordan: available at: http://smeadvisorarabia.com [22 Jun 2015].

19. Zumlot, I. (2013). The New Managerial Accounting Techniques and their Effect on Raising the Credit Efficiency of Corporations Listed in Palestine Exchange. 